\title{
Vitamin D status of children with severe early childhood caries: a case-control study
}

\author{
Robert J Schroth ${ }^{1,2,4^{*}}$, Jeremy A Levi ${ }^{1,2}$, Elizabeth A Sellers ${ }^{1,2}$, James Friel ${ }^{1,2}$, Eleonore Kliewer ${ }^{1,2}$ \\ and Michael EK Moffatt ${ }^{1,2,3}$
}

\begin{abstract}
Background: Severe Early Childhood Caries (S-ECC) affects the health and well-being of young children. There is limited research in this area, though evidence suggests that children with S-ECC are at an increased risk of malnutrition. The purpose of this study was to determine the association between vitamin D (25(OH)D) levels and S-ECC.

Methods: This case-control study was conducted from 2009 to 2011 in the city of Winnipeg, Manitoba, Canada. 144 preschool children with S-ECC were recruited from a local health centre on the day of their slated dental surgery under general anesthetic. 122 caries-free controls were recruited from the community. Children underwent a blood draw for vitamin D $(25(\mathrm{OH}) \mathrm{D})$, calcium, parathyroid hormone, and albumin levels. Parents completed an interviewed questionnaire assessing the child's nutritional habits, oral health, and family demographics. Analyses included descriptive and bivariate statistics as well as multiple and logistic regression. A p value $\leq 0.05$ was significant.

Results: The mean age of participants was $40.8 \pm 14.1$ months. Children with S-ECC had significantly lower mean 25 $(\mathrm{OH}) \mathrm{D}(68.9 \pm 28.0 \mathrm{nmol} / \mathrm{L}$ vs. $82.9 \pm 31.1, p<0.001)$, calcium $(\mathrm{p}<0.001)$, and albumin $(\mathrm{p}<0.001)$ levels, and significantly higher parathyroid hormone $(p<0.001)$ levels than those caries-free. Children with S-ECC were significantly more likely to have vitamin $D$ levels below recognized thresholds for optimal and adequate status (i.e. $<75$ and $<50 \mathrm{nmol} / \mathrm{L}$, respectively). Multiple regression analysis revealed that S-ECC, infrequent milk consumption, and winter season were significantly associated with lower 25(OH)D concentrations. Low 25(OH)D levels, low household income, and poorer ratings of the child's general health were significantly associated with S-ECC on logistic regression.
\end{abstract}

Conclusion: Children with S-ECC appear to have relatively poor nutritional health compared to caries-free controls, and were significantly more likely to have low vitamin D, calcium, and albumin concentrations and elevated PTH levels.

Keywords: Early childhood caries, Vitamin D, Nutritional status, Calcium, Parathyroid hormone, Preschool children

\section{Background}

Early Childhood Caries (ECC) is the most common chronic disease of childhood and is defined as any decay in the primary dentition of children $<72$ months of age $[1,2]$. Some children develop a rampant subtype of ECC termed Severe Early Childhood Caries (S-ECC), a condition known to affect health and well-being [3]. The extent of decay that they experience generally warrants rehabilitative dental surgery under general anesthesia (GA). Unfortunately, dental surgery is the most common day surgical procedure at most Canadian pediatric hospitals

\footnotetext{
*Correspondence: umschrot@cc.umanitoba.ca

${ }^{1}$ The University of Manitoba, Winnipeg, Canada

${ }^{2}$ The Manitoba Institute of Child Health, Winnipeg, Canada

Full list of author information is available at the end of the article
}

[4]. While dental surgery targets the visible signs of the disease, our understanding of the systemic influence of SECC on overall health is limited.

Quality of life is reduced among those suffering from SECC $[3,5,6]$. This can include pain, disturbed sleep and behavioural changes [6-8]. Children with severe decay can also have altered eating habits and preferences $[5,9]$. Therefore, rampant caries can influence nutritional health. A few reports reveal that some may be suffering from a degree of malnutrition, specifically anaemia and low iron concentrations, and have altered growth patterns impacting height and body mass index [10-13]. It is plausible that those with S-ECC are also deficient in important vitamins and nutrients, including vitamin D [14].

\section{Ciomed Central}

(c) 2013 Schroth et al.; licensee BioMed Central Ltd. This is an open access article distributed under the terms of the Creative Commons Attribution License (http://creativecommons.org/licenses/by/2.0), which permits unrestricted use, distribution, and reproduction in any medium, provided the original work is properly cited. 
Vitamin D regulates calcium levels and plays a key role in craniofacial development and the maintenance of good oral health. There are two main sources of obtaining vitamin D: endogenous synthesis and exogenous attainment from diet and supplementation $[15,16]$. It has a critical role in enamel, dentin, and oral bone formation as ameloblasts and odontoblasts are target cells for 1,25-dihydroxyvitamin D, the active form of vitamin D [17]. Deficiency in vitamin $\mathrm{D}$ during periods of tooth development may also result in developmental defects [17] including enamel hypoplasia, a significant risk factor for S-ECC. Vitamin D is associated with the two main oral diseases, caries and periodontal disease [14,18-23]. In general, higher serum levels of 25-hydroxyvitamin D (25(OH)D) are associated with improved oral health outcomes [14,20-22]. Vitamin D also has an immunological role as it can induce the production of antimicrobial peptides such as cathelicidin and certain defensins, which protect us from oral pathogens [22,24].

The purpose of this study was to determine the association between serum concentrations of $25(\mathrm{OH}) \mathrm{D}$ and $\mathrm{S}$ $\mathrm{ECC}$ in preschool children.

\section{Methods}

A cross-sectional case-control study was undertaken to test the hypothesis that children with S-ECC have lower serum $25(\mathrm{OH}) \mathrm{D}$, calcium, albumin, and higher parathyroid hormone (PTH) levels than caries-free controls. Differences in ferritin and haemoglobin between these groups has previously been reported in this sample [12]. This study was approved by the University of Manitoba's Health Research Ethics Board, the Misericordia Health Centre (MHC), and the Health Sciences Centre (HSC), Winnipeg, Canada. All parents provided written informed consent at recruitment, and a small honorarium was provided.

From October 2009 to August 2011, otherwise-healthy children with S-ECC were recruited from the MHC in Winnipeg, Canada ( $49^{\circ} 53^{\prime}$ North) on the day of their dental surgery. Since the case definition for S-ECC is age specific, participants needed to be $\leq 71$ months of age [25]. Age-matched caries-free controls were recruited from the community by advertisement and underwent a dental screening by a study team member (RJS). Children were assessed using the dmft index (a cumulative score of decayed, missing, filled primary teeth). Those having a dmft score of 0 were considered caries-free.

Caregivers completed a questionnaire administered by staff which collected information about the child and caregiver, dietary intakes, use of supplements, sun exposure and skin pigmentation, oral hygiene behaviours, and socioeconomic factors including household income, parental education level, and receipt of government assistance [12]. This instrument was based upon a previously piloted questionnaire [14].
Venipunctures for children with S-ECC were drawn by the attending anesthetist during surgery while blood samples from controls were obtained by a research nurse at the Manitoba Institute of Child Health following the application of a topical anaesthetic (EMLA) to the anticubital fossa. Serum analysis for calcium, PTH, and albumin was performed by the Department of Biochemistry and Genetics Laboratory at HSC. In cases where the serum albumin levels were below the appropriate thresholds for a child's age, the corrected calcium level was used in place of the standard calcium values. Diagnostic Services of Manitoba laboratory reference ranges were adopted for calcium (2.1$2.6 \mathrm{mmol} / \mathrm{L})$, albumin $(35-47 \mathrm{~g} / \mathrm{L}$ for those $<48$ months and 33-39 g/L for those $\geq 48$ months), and PTH (7$50 \mathrm{ng} / \mathrm{L})$. Assays for $25(\mathrm{OH}) \mathrm{D}$, the main circulating form of vitamin $\mathrm{D}$, were conducted by the Hospitals in Common Laboratory (HICL) at Mount Sinai Hospital in Toronto, Canada using Chemiluminescence Immunoassay. The key thresholds used to quantify $25(\mathrm{OH}) \mathrm{D}$ levels within this study were $\geq 75 \mathrm{nmol} / \mathrm{L}$ (optimal based on HICL and HSC), $\geq 50 \mathrm{nmol} / \mathrm{L}$ (adequate based on Institute of Medicine (IOM)), and $<35 \mathrm{nmol} / \mathrm{L}$ (common threshold used to denote deficiency) $[14,16,26-28]$.

A minimum sample of 120 children in each group was expected to provide $80 \%$ power to detect a one-tailed difference in $25(\mathrm{OH}) \mathrm{D}$ levels between the groups at $\alpha=0.05$. $\mathrm{Lab}$ and questionnaire data were entered into an Excel (Microsoft Office) spreadsheet and analyzed using Number Cruncher Statistical Software (NCSS) version 7.0 (Kaysville, Utah). Analysis included descriptive statistics (frequencies, means \pm Standard Deviations (SD)), Chi-square analysis, and t-tests. Unadjusted odds ratios (OR) and 95\% confidence intervals $(\mathrm{CI})$ were also calculated. Multiple regression analysis was performed for mean 25(OH)D including independent variables significantly associated with vitamin $\mathrm{D}$ levels on bivariate analysis or known to influence vitamin D status. Logistic regression for S-ECC including variables associated at the bivariate level was also performed. In both models, some variables were excluded when there was evidence of multi-colinearity. A p value $\leq 0.05$ was significant.

\section{Results}

A total of 266 children (51.1\% male) participated; 144 children with S-ECC and 122 caries-free. For various reasons, blood samples were only collected for $97.9 \%(n=141)$ of children with S-ECC and 99.2\% $(n=121)$ of controls. The mean age was $40.8 \pm 14.1$ months. The groups were well matched for age and sex as there were no significant differences ( $p=0.14$ and $p=0.37$, respectively). Characteristics of participants and their parent or caregiver appear in Table 1. As S-ECC is influenced by the social determinants of health, there were differences in parental education levels $(\mathrm{p}<0.001)$ and household income $(\mathrm{p}<0.001)$ between 


\begin{tabular}{|c|c|c|c|c|c|c|}
\hline Male & 136 & $70(51.5)$ & $43.1,59.9$ & $66(48.5)$ & $40.1,56.9$ & 0.37 \\
\hline Female & 130 & $74(56.9)$ & $48.4,65.4$ & $56(43.1)$ & $34.6,51.6$ & \\
\hline Height $(\mathrm{cm})^{\dagger}$ & $98.4 \pm 9.7$ & $99.3 \pm 8.1$ & / & $97.3 \pm 11.1$ & / & 0.10 \\
\hline Weight $(\mathrm{kg})^{\dagger}$ & $16.4 \pm 3.7$ & $17.0 \pm 3.3$ & / & $15.8 \pm 4.0$ & / & 0.01 \\
\hline \multicolumn{7}{|l|}{ Skin colour } \\
\hline Dark/Mid-colour & 116 & $76(65.6)$ & $56.9,74.2$ & $40(34.5)$ & $25.8,43.1$ & 0.001 \\
\hline Light & 150 & $68(45.3)$ & $37.4,53.3$ & $82(54.7)$ & $46.7,62.6$ & \\
\hline \multicolumn{7}{|l|}{ Multivitamin Use } \\
\hline Yes & 143 & $76(53.1)$ & $45.0,61.3$ & $67(46.9)$ & $38.7,55.0$ & 0.73 \\
\hline No & 123 & $68(55.3)$ & $46.5,64.1$ & $55(44.7)$ & $35.9,53.5$ & \\
\hline Age started cleaning mouth (Months) ${ }^{\dagger}$ & $12.9 \pm 8.6$ & $14.5 \pm 9.5$ & / & $10.9 \pm 7.1$ & / & $<0.001$ \\
\hline Mean age at first dental visit (Months) ${ }^{\dagger}$ & $26.2 \pm 11.8$ & $27.0 \pm 11.9$ & I & $24.7 \pm 11.7$ & / & 0.17 \\
\hline \multicolumn{7}{|l|}{ Breast-fed $^{*}$} \\
\hline Yes & 204 & $93(45.6)$ & $38.8,52.4$ & $111(54.4)$ & $48.0,61.0$ & $<0.001$ \\
\hline No & 61 & $50(82.0)$ & $72.3,91.6$ & $11(18.0)$ & $8.4,27.7$ & \\
\hline \multicolumn{7}{|l|}{ Bottle-fed ${ }^{*}$} \\
\hline Yes & 194 & $114(58.8)$ & $51.8,65.7$ & $80(41.2)$ & $34.3,48.2$ & 0.01 \\
\hline No & 71 & $29(40.8)$ & $29.4,52.3$ & $42(59.2)$ & $47.7,70.6$ & \\
\hline \multicolumn{7}{|l|}{ Parent/Caregiver } \\
\hline \multicolumn{7}{|l|}{ Caregiver status } \\
\hline Mother & 247 & $132(53.4)$ & $47.2,59.7$ & $115(46.6)$ & $40.0,53.0$ & 0.62 \\
\hline Father & 15 & $9(60.0)$ & $35.2,84.8$ & $6(40.0)$ & $15.2,64.8$ & \\
\hline Other & 4 & $3(75.0)$ & $32.6,117.4$ & $1(25.0)$ & $-17.4,67.4$ & \\
\hline Graduated high school ${ }^{*}$ & & & & & & $<0.001$ \\
\hline Grade 12 or higher & 197 & $86(43.7)$ & $36.7,50.6$ & $111(56.3)$ & $49.4,63.3$ & \\
\hline$<$ Grade 12 & 66 & $55(83.3)$ & $74.0,92.0$ & $11(16.7)$ & $7.7,25.7$ & \\
\hline \multicolumn{7}{|l|}{ Afford dental care } \\
\hline Yes & 222 & $123(55.4)$ & $48.9,61.9$ & $99(44.6)$ & $38.1,51.1$ & 0.28 \\
\hline No & 41 & $19(46.3)$ & $331.1,61.6$ & $22(53.7)$ & $38.0,69.0$ & \\
\hline Receives social assistance ${ }^{*}$ & & & & & & $<0.001$ \\
\hline Yes & 103 & 81 (78.6) & $70.7,86.6$ & $22(21.4)$ & $13.4,29.3$ & \\
\hline No & 158 & $61(38.6)$ & $31 \cdot 0,46.2$ & $97(61.4)$ & $53.8,69.0$ & \\
\hline Yearly household income ${ }^{*}$ & & & & & & $<0.001$ \\
\hline$<\$ 28000$ & 119 & $85(71.4)$ & $63.3,79.5$ & 34 (28.6) & $20.5,36.7$ & \\
\hline$>\$ 28000$ & 134 & 47 (35.1) & $27.0,43.0$ & 87 (64.9) & $56.8,73.0$ & \\
\hline
\end{tabular}

S-ECC $=$ Severe Early Childhood Caries.

tt-test, * *hi-square.

$95 \% \mathrm{Cl}=95 \%$ Confidence Intervals.

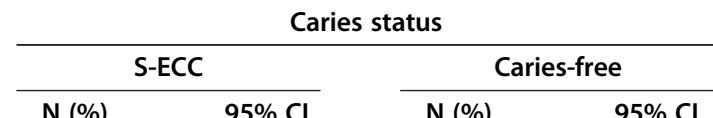

\begin{tabular}{l} 
Variable \\
\hline Child \\
Child's age (M \\
Sex \\
Height $(\mathrm{cm})^{\dagger}$ \\
Weight $(\mathrm{kg})^{\dagger}$ \\
Skin colour ${ }^{*}$
\end{tabular}

Child's age (Months) ${ }^{\dagger}$

\begin{tabular}{l} 
Variable \\
\hline Child \\
Child's age (M \\
Sex \\
Height $(\mathrm{cm})^{\dagger}$ \\
Weight $(\mathrm{kg})^{\dagger}$ \\
Skin colour ${ }^{*}$
\end{tabular}

$40.8 \pm 14.1$

$42.0 \pm 11.9$

/

$39.4 \pm 16.3$

Table 1 Association between caries status and child and caregiver characteristics

\begin{tabular}{l} 
Variable \\
\hline Child \\
Child's age ( \\
Sex \\
Height $(\mathrm{cm})^{\dagger}$ \\
Weight $(\mathrm{kg})^{\dagger}$ \\
Skin colour
\end{tabular}

\begin{tabular}{l} 
Variable \\
\hline Child \\
Child's age (M \\
Sex \\
Height $(\mathrm{cm})^{\dagger}$ \\
Weight $(\mathrm{kg})^{\dagger}$ \\
Skin colour
\end{tabular}

$98.4 \pm 9.7$

$99.3 \pm 8.1$

$7.0 \pm 3.3$

76 (65.6)

$56.9,74.2$

(34.5)

$25.8,43$

0.14

$$
\text { Light }
$$

Yes

$$
123
$$

$12.9 \pm 8.6$

$14.5 \pm 9.5$

Mean age at first dental visit (Months) ${ }^{\dagger}$

Yes

$93(45.6)$

$38.8,52.4$

$111(54.4)$

$48.0,61.0$

0.001

P value 
groups, with lower levels of both education and household income in the S-ECC group. Fewer children in the $\mathrm{S}$-ECC group were reported as having good or very good oral health compared to controls $(19.4 \%$ vs. $95.9 \%$, $\mathrm{p}<0.001)$. Significantly more children with S-ECC had a first visit to the dentist for a dental problem (e.g. pain or caries) than controls ( $40.7 \%$ vs. $5.4 \%, \mathrm{p}<0.001)$. Additionally, fewer caregivers of children with S-ECC indicated that their child's overall health was very good compared to those whose children were caries-free $(58.3 \%$ vs. $82.8 \%, \mathrm{p}<0.001)$.

One child had a mean 25(OH)D level above four SD from the mean and was excluded from subsequent analyses. The mean 25(OH)D concentration for the entire sample was $75.4 \pm 30.2 \mathrm{nmol} / \mathrm{L}$. A total of 136 children (52.1\%) had levels $<75 \mathrm{nmol} / \mathrm{L}$, indicating suboptimal vitamin D while 43 children (16.5\%) had inadequate vitamin D $(<50 \mathrm{nmol} / \mathrm{L})$. Additionally, 16 (6.1\%) had deficient vitamin D concentrations $(<35 \mathrm{nmol} / \mathrm{L})$.

More frequent intake of foods containing or fortified with vitamin D (e.g. liver, eggs, fish, fortified orange juice) were not significantly associated with higher mean 25 $(\mathrm{OH}) \mathrm{D}$ levels (data not shown). The exception were regular milk drinkers ( $\geq 5$ servings weekly), who had significantly higher mean vitamin $\mathrm{D}$ levels than non-regular milk drinkers $(76.6 \pm 30.3 \mathrm{nmol} / \mathrm{L}$ vs. $63.2 \pm 27.0, \mathrm{p}=$ $0.042)$. Those presently taking vitamin $\mathrm{D}$ drops also had higher $25(\mathrm{OH}) \mathrm{D}$ levels $(92.2 \pm 34.6 \mathrm{nmol} / \mathrm{L}$ vs. $72.2 \pm 28.2$, $\mathrm{p}<0.001)$.

There were no apparent differences in the intake of foods containing vitamin D between the S-ECC and caries-free groups, including the frequency of milk consumption (data not shown). However, significantly more children receiving vitamin $\mathrm{D}$ drops belonged to the caries-free group $(14.0 \%$ S-ECC $(n=6)$ vs. $86.0 \%$ caries-free $(n=37), p<$ 0.001 ). There was also no significant difference in multivitamin usage between the groups (76 with S-ECC vs. 67 caries-free, $p=0.73)$. Significantly more children in the $S$ ECC group were bottle-fed compared to controls $(\mathrm{p}=0.01)$ and bottle-fed to a later age $(19.7 \pm 8.7$ months vs. $16.4 \pm$ 7.7, $\mathrm{p}=0.02)$. Meanwhile, fewer children with S-ECC were breastfed compared to the caries-free group $(\mathrm{p}<0.001)$. There was no difference in the frequency of daily "betweenmeal" snacking between the groups (93.8\% S-ECC vs. 96.7\% caries-free, $p=0.39$, Fisher's Exact Test).

There was no significant difference between the two groups with respect to premature birth $(\mathrm{p}=0.88)$, whether mothers took vitamin $\mathrm{D}$ supplements during pregnancy $(\mathrm{p}=0.92)$, or maternal milk intake during pregnancy $(\mathrm{p}=$ $0.56)$ (data not shown).

Mean 25(OH)D levels were significantly lower among children with S-ECC than caries-free controls $(68.9 \pm$ $28.0 \mathrm{nmol} / \mathrm{L}$ vs. $82.9 \pm 31.1, \mathrm{p}<0.001$ ) (Table 2). Even after stratifying by season and only analyzing data collected during the winter (October-April) to control for endogenous production, a statistically significant difference remained $(63.5 \pm 27.7 \mathrm{nmol} / \mathrm{L}$ vs. $79.4 \pm 26.7, \mathrm{p}<0.001)$.

The 25(OH)D distribution based on caries-status appears in Table 2. Those in the S-ECC group were found to have relatively poor vitamin D status compared to cariesfree children. Significantly more children with S-ECC had suboptimal 25(OH)D concentrations $(<75 \mathrm{nmol} / \mathrm{L})$ compared to their caries-free peers $(\mathrm{p}=0.006)($ Table 2$)$. In fact, children with $25(\mathrm{OH}) \mathrm{D}$ levels below this threshold were twice as likely to have S-ECC. This relationship was also present when the IOM threshold for adequacy $(50 \mathrm{nmol} / \mathrm{L})$ was applied $(\mathrm{p}=0.05, \mathrm{OR}=0.5)$. When the "deficient" threshold $(<35 \mathrm{nmol} / \mathrm{L})$ was applied, this relationship failed to reach significance $(\mathrm{p}=0.12$ (Fisher's Exact Test), $\mathrm{OR}=2.7$ ).

There was no association between the education level of the primary caregiver and the child's vitamin D status with respect to both the mean levels and the proportion with levels $\geq 75 \mathrm{nmol} / \mathrm{L} \quad(\mathrm{p}=0.74$ and $\mathrm{p}=0.35$, respectively $)$. However, higher yearly household incomes were associated with higher mean $25(\mathrm{OH}) \mathrm{D}$ levels and having concentrations $\geq 75 \mathrm{nmol} / \mathrm{L}(\mathrm{p}=0.002$ and $\mathrm{p}=0.002$, respectively).

Differences in mean calcium, albumin, and PTH concentrations between the groups are also reported in Table 2 . Children with S-ECC had significantly lower mean calcium $(\mathrm{p}<0.001)$ and mean albumin $(\mathrm{p}<0.001)$ levels as well as higher mean PTH concentrations $(\mathrm{p}<0.001)$ than controls. Despite small cell sizes, it should be noted that all of the children with low calcium concentrations belonged to the S-ECC group. Children with S-ECC were 23.6 times more likely to have elevated PTH levels compared to controls and 3.6 times more likely to have abnormally low albumin concentrations (Table 2).

Multiple regression for $25(\mathrm{OH}) \mathrm{D}$ concentrations revealed that levels were significantly and independently associated with S-ECC, regular milk consumption, and season of assessment but not household income and or the use of vitamin D drops (Table 3). S-ECC, infrequent milk intake, and winter season were associated with lower 25(OH)D levels, but not household income or vitamin D drop use. Logistic regression for caries status was also performed, revealing that lower household income, poorer ratings of children's general health, and lower vitamin D levels were significantly associated with S-ECC (Table 4).

\section{Discussion}

The purpose of this study was to determine whether children with S-ECC have different nutritional profiles than their caries-free peers, specifically vitamin $\mathrm{D}$, calcium and albumin status. While historical evidence suggests that vitamin D supplementation can prevent caries onset and progression, much of this research has been overlooked $[18,29,30]$. In a pilot study published in 2012, we were the 
Table 2 25(OH)D, Calcium, Albumin, and PTH status by S-ECC and caries-free group

\begin{tabular}{|c|c|c|c|c|c|c|c|}
\hline \multirow[t]{3}{*}{ Variable } & & \multirow[t]{3}{*}{ Overall value } & \multicolumn{4}{|c|}{ Caries status } & \multirow[t]{3}{*}{$P$ value } \\
\hline & & & \multicolumn{2}{|c|}{ S-ECC } & \multicolumn{2}{|c|}{ Caries-Free } & \\
\hline & & & N (\%) & $95 \% \mathrm{Cl}$ & N (\%) & $95 \% \mathrm{Cl}$ & \\
\hline \multicolumn{8}{|l|}{$25(\mathrm{OH}) \mathrm{D}$ status } \\
\hline Mean $\left(\mathrm{nmol} / \mathrm{L}^{+}{ }^{\dagger}\right.$ & & $75.4 \pm 30.2$ & $68.9 \pm 27.9$ & / & $82.9 \pm 31.1$ & / & $<0.001$ \\
\hline \multicolumn{8}{|c|}{ Optimal* $(\geq 75 \mathrm{nmol} / \mathrm{L})$} \\
\hline & Yes & 125 & $56(44.8)$ & $36.1,53.5$ & $69(55.2)$ & $46.0,64.0$ & 0.006 \\
\hline & No & 136 & $84(61.8)$ & $53.6,69.9$ & $52(38.2)$ & $30.1,46.4$ & \\
\hline \multicolumn{8}{|c|}{ Adequate $^{*}(\geq 50 \mathrm{nmol} / \mathrm{L})$} \\
\hline & Yes & 218 & $111(50.9)$ & $44.3,57.6$ & $107(49.1)$ & $42.4,55.7$ & 0.05 \\
\hline & No & 43 & $29(67.4)$ & $53.4,81.4$ & $14(32.6)$ & $18.6,46.6$ & \\
\hline \multicolumn{8}{|c|}{ Deficient* (< $35 \mathrm{nmol} / \mathrm{L})$} \\
\hline & Yes & 16 & $12(75.0)$ & $53.8,96.2$ & $4(25.0)$ & $3.8,46.2$ & $0.12^{\mathrm{a}}$ \\
\hline & No & 245 & $128(52.2)$ & $46.0,58.5$ & $117(47.8)$ & $41.5,54.0$ & \\
\hline \multicolumn{8}{|l|}{ Calcium status } \\
\hline Mean $(\mathrm{mmol} / \mathrm{L})^{\dagger}$ & & $2.3 \pm 0.1$ & $2.2 \pm 0.1$ & / & $2.4 \pm 0.1$ & / & $<0.001$ \\
\hline \multicolumn{8}{|l|}{ Low calcium* } \\
\hline & Yes & 10 & $10(100.0)$ & 100,100 & $0(0.0)$ & 0,0 & $0.002^{\mathrm{a}}$ \\
\hline & No & 248 & $130(52.4)$ & $46.2,58.6$ & $118(47.6)$ & $41.4,53.8$ & \\
\hline \multicolumn{8}{|c|}{ Low calcium (Corrected)* } \\
\hline & Yes & 6 & $6(100)$ & 100,100 & $0(0.0)$ & 0,0 & \\
\hline & No & 252 & $134(53.2)$ & $47.0,59.3$ & $118(46.8)$ & $41 \cdot 0,53 \cdot 0$ & $0.03^{\mathrm{a}}$ \\
\hline \multicolumn{8}{|l|}{ PTH status } \\
\hline Mean $(\mathrm{ng} / \mathrm{L})^{\dagger}$ & & $47.3 \pm 22.0$ & $59.1 \pm 21.8$ & / & $32.9 \pm 10.8$ & / & $<0.001$ \\
\hline \multicolumn{8}{|l|}{ Elevated PTH* } \\
\hline & Yes & 92 & $85(92.4)$ & $87.0,97.8$ & $7(7.6)$ & $2.2,13.0$ & $<0.001$ \\
\hline & No & 162 & $55(34.0)$ & $26.7,41.2$ & $107(66.0)$ & $58.7,73.3$ & \\
\hline \multicolumn{8}{|l|}{ Albumin status } \\
\hline Mean $(g / L)^{+}$ & & $38.4 \pm 3.7$ & $36.8 \pm 3.1$ & / & $40.3 \pm 3.5$ & / & $<0.001$ \\
\hline \multicolumn{8}{|l|}{ Low albumin* } \\
\hline & Yes & 33 & $26(78.8)$ & $64.8,92.7$ & $7(21.2)$ & $7.3,35.2$ & 0.002 \\
\hline & No & 225 & 114 (50.7) & $44.1,57.2$ & 111 (49.3) & $43.0,56.0$ & \\
\hline
\end{tabular}

S-ECC = Severe Early Childhood Caries.

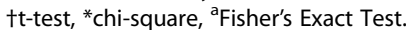

$95 \% \mathrm{Cl}=95 \%$ Confidence Intervals.

Table 3 Multiple regression for mean vitamin D level

\begin{tabular}{lccc}
\hline Variable & Unstandardized regression coefficient $(\mathbf{b})$ & $\mathbf{\pm 9 5 \%}$ confidence interval & P value \\
\hline Intercept & 71.01 & $/$ & $1.24,9.42$ \\
S-ECC (Reference $=$ Yes) & 5.33 & $-13.16,-0.03$ & 0.01 \\
Regular milk drinker (Reference $=$ Yes) & -6.60 & $1.37,9.06$ & 0.05 \\
Season (Reference $=$ Winter) & 5.22 & $2.01,-6.13$ & 0.008 \\
Vitamin D drop user (Reference $=$ Yes) & -2.17 & $2.06,-1.32$ & 0.28 \\
Yearly income (Reference $=<28$ k) & 2.73 & 0.19 \\
\hline
\end{tabular}

S-ECC = Severe Early Childhood Caries.

Adjusted $\mathrm{R}^{2}=8.37 \%$. 
Table 4 Logistic regression for S-ECC

\begin{tabular}{lccc}
\hline Variable & Adjusted odds ratio & $\mathbf{\pm 9 5 \%}$ confidence interval for odds ratio & P value \\
\hline Age started cleaning teeth & 0.97 & $0.94,1.01$ & 0.12 \\
Bottle fed (Reference $=$ Yes) & 0.73 & $0.37,1.46$ & 0.37 \\
General health (Reference = Very Good) & 3.04 & $1.50,6.15$ & 0.002 \\
Mean vitamin D & 1.01 & $1.00,1.02$ & 0.04 \\
Vitamin D drop usage (Reference = Yes) & 1.51 & $0.81,2.82$ & 0.19 \\
Yearly income (Reference $=<28$ k) & 0.30 & $0.16,0.55$ & $<0.001$ \\
\hline
\end{tabular}

S-ECC $=$ Severe Early Childhood Caries.

first to specifically report differences in actual serum 25 $(\mathrm{OH}) \mathrm{D}$ levels between children with and without severe decay [14]. The present study involved a substantially larger sample, and reinforces the observed association between 25(OH)D levels and S-ECC.

Much of the early research in this field was conducted by May Mellanby, who identified an association between vitamin D supplementation and reduced caries-risk $[18,31]$. Recently, a meta-analysis reported that vitamin D supplementation in childhood can help prevent caries [30], and it has also been suggested that concentrations of $25(\mathrm{OH}) \mathrm{D}$ between $75-100 \mathrm{nmol} / \mathrm{L}$ may reduce the risk for caries [22]. Our study supports these findings, as caries-free children were twice as likely to have optimal $25(\mathrm{OH}) \mathrm{D}$ concentrations $(\geq 75 \mathrm{nmol} / \mathrm{L})$ and those with S-ECC were at nearly three times the odds of having deficient levels $(<35 \mathrm{nmol} / \mathrm{L})$.

The mean $25(\mathrm{OH}) \mathrm{D}$ level in our sample was adequate, mirroring our pilot study findings [14] and those of the Canadian Health Measures Survey [32]. This may be attributed to regular milk intake, which was common in both groups. Regular milk drinkers had better vitamin D concentrations, a finding supported by a large-scale clinical study observing an association between frequent milk consumption and increased 25(OH)D [33].

Regression techniques were employed to determine whether the association between caries and vitamin D status remained after controlling for confounders. Even after controlling for seasonal influence on endogenous synthesis, low household income, and infrequent consumption of vitamin D drops and milk, the significant association remained. Similarly, the association between $25(\mathrm{OH}) \mathrm{D}$ concentrations and S-ECC was significant after logistic regression while controlling for factors such as general health status, the age when teeth cleaning was first started, and household finances. As there was a strong relationship between education and income, education was not included in the model to avoid multi-colinearity.

Our study also reports that those with S-ECC had significantly lower calcium and elevated PTH levels, as observed in our pilot study [14]. These metabolites were not, however, included in the regression models as they were strongly correlated with $25(\mathrm{OH}) \mathrm{D}$ levels. This multi-colinearity is expected, as these variables are physiologically interrelated.

Children with S-ECC were found to have significantly lower albumin levels than caries-free controls. Our finding that $18.6 \%$ in the S-ECC group had low albumin is comparable to the $15 \%$ reported in another Canadian sample. Albumin is a serum protein that can be used as an additional indicator of overall nutritional status and malnutrition [34]. A deficiency in this protein in conjunction with undesirable vitamin D, PTH, and calcium levels may suggest that children with S-ECC have nutritional deficiencies. We have recently reported that children with S-ECC from this same study group were more likely to have low ferritin and hemoglobin levels along with iron deficiency anaemia [12]. Others have also reported that rampant caries can negatively impact nutritional health status and well-being $[3,10,13,35]$. Therefore, health professionals should be aware of the potential nutritional deficiencies in children suffering from extensive dental caries.

It is important to consider how S-ECC and poor nutritional status are connected. Vitamin D and calcium disturbances during tooth development may result in dentin and enamel defects, which can increase the risk for caries. However, children with S-ECC may experience ongoing pain which may alter their eating habits. This can improve after dental surgery under GA [3,9]. Avoidance of food because of severe dental problems may, in turn, contribute to the nutritional deficiencies identified in this sample [12].

This case-control study has some limitations. While we did not assess caries rates, all children with S-ECC had multiple cavitated caries lesions necessitating surgery. The cross-sectional design did not allow us to distinguish between cause and effect. Additionally, children in our study were matched by age and sex, but we were unable to match by household economics and caregiver education levels. The majority of S-ECC children came from lowerincome households. Identifying caries-free controls living in these same communities proved challenging. Naturally, some factors are difficult to control for as they are critical to explaining why children are at risk for caries (e.g. household income, parental education, etc.). Fortunately, we controlled for household income in the regression models. Additionally, the caregiver questionnaire involved 
retrospective questions on prenatal diet and the child's first 12 months of life which may have introduced recall bias. In retrospect, a comprehensive food frequency assessment would have been a useful addition to the study. Despite these limitations, the large sample size provided sufficient statistical power, allowing greater confidence in our findings.

\section{Conclusion}

Based on the findings of this study, we conclude that:

- Children with S-ECC appear to be at significantly greater odds of having low vitamin D status compared to their caries-free controls.

- Children with S-ECC are likely malnourished, as they displayed significantly lower levels of calcium and serum albumin as well as higher levels of PTH compared to the control group.

This study suggests a clear relationship between vitamin $\mathrm{D}$ levels and the caries status of preschool children. As a result of these findings, it may be advantageous for primary care providers (including dentists and physicians) to consider serum $25(\mathrm{OH}) \mathrm{D}$ status when assessing the child's overall health. Specifically, recommending vitamin D supplementation for children at risk of dental caries may result in a decrease in the overall prevalence of S-ECC and, ultimately, reduce the burden on pediatric day surgery centres.

\section{Abbreviations \\ Cl: Confidence intervals; dmft: decayed, missing, filled teeth; ECC: Early childhood caries; GA: General anesthesia; HSC: Health sciences centre; IOM: Institute of medicine; MHC: Misericordia health centre; OR: Odds ratio; PTH: Parathyroid hormone; SD: Standard deviation; S-ECC: Severe early childhood caries.}

\section{Competing interests}

The authors declare that no competing interests (financial or personal) exist with regards to this manuscript.

\section{Authors' contributions}

RS: Conception and design, acquisition of data, analysis and interpretation of data, drafting of article, revising article critically for important intellectual content, and final approval of version to be published. J: Acquisition of data, analysis and interpretation of data, drafting of article, revising article critically for important intellectual content, and final approval of version to be published. ES: Analysis and interpretation of data, revising article critically for important intellectual content, and final approval of version to be published. JF: Analysis and interpretation of data, revising article critically for important intellectual content, and final approval of version to be published. EK: Acquisition of data, revising article critically for important intellectual content, and final approval of version to be published. MM: Conception and design, analysis and interpretation of data, revising article critically for important intellectual content, and final approval of version to be published. All authors read and approved the final manuscript.

\section{Acknowledgements}

Operating funds were provided by the Manitoba Institute of Child Health. Dr. Schroth holds a Clinical Research Professorship in Population Medicine from the Manitoba Medical Service Foundation and the Manitoba Health Research Council. Jeremy Levi held a Summer Studentship Research Award from the Manitoba Institute of Child Health. The authors would like to acknowledge the assistance of Betty-Anne Mittermuller for data entry, the staff at the Misericordia Health Centre, Dr. S. Ullyot, participating pediatric dentists, and participating children and their parents.

Funding

The Manitoba Institute of Child Health.

\section{Author details}

${ }^{1}$ The University of Manitoba, Winnipeg, Canada. ${ }^{2}$ The Manitoba Institute of Child Health, Winnipeg, Canada. ${ }^{3}$ Winnipeg Regional Health Authority, Winnipeg, Canada. ${ }^{4}$ Department of Preventive Dental Science, Faculty of Dentistry, Department of Pediatrics \& Child Health, Faculty of Medicine, University of Manitoba, 507 - 715 McDermot Avenue, Winnipeg MB R3E 3P4, Canada.

Received: 3 June 2013 Accepted: 23 October 2013

Published: 25 October 2013

\section{References}

1. Drury TF, Horowitz AM, Ismail Al, et al: Diagnosing and reporting early childhood caries for research purposes. A report of a workshop sponsored by the National Institute of Dental and Craniofacial Research, the Health Resources and Services Administration, and the Health Care Financing Administration. J Public Health Dent 1999, 59:192-197.

2. American Academy of Pediatric Dentistry: Policy on early childhood caries (ECC): classifications, consequences, and preventive strategies. Pediatr Dent 2012, 34(6):50-52.

3. Schroth RJ, Harrison RL, Moffatt ME: Oral health of indigenous children and the influence of early childhood caries on childhood health and well-being. Pediatr Clin North Am 2009, 56:1481-1499.

4. Canadian Paediatric Decision Support Network: Canadian Paediatric Decision Support Network Annual Report April 2003-March 2004. Ottawa: Canadian Paediatric Decision Support Network. Canadian Association of Paediatric Health Centres; 2004:1-54.

5. Feitosa S, Colares V, Pinkham J: The psychosocial effects of severe caries in 4-year-old children in Recife, Pernambuco, Brazil. Cad Saude Publica 2005, 21:1550-1556

6. Williamson R, Oueis $H$, Casamassimo PS, et al: Association between early childhood caries and behavior as measured by the child behavior checklist. Pediatr Dent 2008, 30:505-509.

7. Thomas CW, Primosch RE: Changes in incremental weight and well-being of children with rampant caries following complete dental rehabilitation. Pediatr Dent 2002, 24:109-113.

8. White H, Lee JY, Vann WF Jr: Parental evaluation of quality of life measures following pediatric dental treatment using general anesthesia. Anesth Prog 2003, 50:105-110.

9. Low W, Tan S, Schwartz S: The effect of severe caries on the quality of life in young children. Pediatr Dent 1999, 21:325-326.

10. Oliveira LB, Sheiham A, Bonecker M: Exploring the association of dental caries with social factors and nutritional status in Brazilian preschool children. Eur J Oral Sci 2008, 116:37-43.

11. Gaur S, Nayak R: Underweight in low socioeconomic status preschool children with severe early childhood caries. J Indian Soc Pedod Prev Dent 2011, 29:305-309.

12. Schroth RJ, Levi J, Kliewer $E$, et al: Association between iron status, iron deficiency anaemia, and severe early childhood caries: a case-control study. BMC Pediatr 2013, 13:22.

13. Clarke M, Locker D, Berall $G$, et al: Malnourishment in a population of young children with severe early childhood caries. Pediatr Dent 2006, 28:254-259.

14. Schroth $\mathrm{R}$, Jeal $\mathrm{N}$, Kliewer $\mathrm{E}$, et al: The relationship between vitamin $\mathrm{D}$ and severe early childhood caries: a pilot study. Int J Vitam Nutr Res 2012, 82:53-62.

15. Grant WB, Holick MF: Benefits and requirements of vitamin D for optimal health: a review. Altern Med Rev 2005, 10:94-111.

16. Holick MF: Vitamin D deficiency. N Engl J Med 2007, 357:266-281.

17. Berdal A, Bailleul-Forestier I, Davideau J, et al: Dento-alveolar bone complex and vitamin D. In Vitamin D. Edited by Feldman D, Pike J, Glorieux F. Burlington: Elsevier Academic Press; 2005:599-607.

18. Mellanby M, Pattison C: The action of vitamin D in preventing the spread and promoting the arrest of caries in children. Br Med J 1928, 2:1079-1082. 
19. Mellanby M: Diet and the teeth. An experimental study. In The effect of diet on dental structure and disease in man. Illth edition. Edited by Medical Research Council. London: His Majesty's Stationery Office; 1934:1-180.

20. Dietrich T, Joshipura K, Dawson-Hughes B, et al: Association between serum concentrations of 25-hydroxyvitamin D3 and periodontal disease in the US population. Am J Clin Nutr 2004, 80:108-113.

21. Grant WB: Vitamin D, periodontal disease, tooth loss, and cancer risk. Lancet Oncol 2008, 9:612-613.

22. Grant WB: A review of the role of solar ultraviolet-B irradiance and vitamin D in reducing risk of dental caries. Dermatoendocrinol 2011, 3:193-198.

23. Hildebolt CF: Effect of vitamin D and calcium on periodontitis. J Periodontol 2005, 76:1576-1587.

24. Hewison M: Vitamin $D$ and the immune system: new perspectives on an old theme. Endocrinol Metab Clin North Am 2010, 39:365-379. table.

25. American Academy of Pediatric Dentistry: Definition of early childhood caries (ECC). Pediatr Dent 2010, 32:15.

26. Whiting SJ, Calvo MS: Overview of the proceedings from experimental biology 2005 symposium: optimizing vitamin D intake for populations with special needs: barriers to effective food fortification and supplementation. J Nutr 2006, 136:1114-1116.

27. Dawson-Hughes B, Heaney RP, Holick MF, et al: Estimates of optimal vitamin D status. Osteoporos Int 2005, 16:713-716.

28. Committee to Review Dietary Reference Intakes for Vitamin D and Calcium FaNB: Dietary reference intakes for calcium and vitamin D. Washington, DC: Institute of Medicine; 2011.

29. McBeath EC, Verlin WA: Further studies on the role of vitamin $D$ in the nutritional control of dental caries in children. J Am Dent Assoc 1942 29:1393-1397.

30. Hujoel PP: Vitamin $D$, and dental caries in controlled clinical trials: systematic review and meta-analysis. Nutr Rev 2013, 71:88-97.

31. Mellanby M: The role of nutrition as a factor in resistance to dental caries. Br Dent J 1937, 62(5):241-252.

32. Langlois $K$, Greene-Finestone L, Little J, et al: Vitamin D status of Canadians as measured in the 2007 to 2009 Canadian Health Measures Survey. Health Reports 2010, 21(1):47-55.

33. Maquire JL, Lebovic G, Kandasamy S, et al: The relationship between cow's milk and stores of vitamin D and iron in early childhood. Pediatrics 2013, 131:e144-e151.

34. Hoffer L: Metabolic consequences of starvation. In Modern nutrition in health and disease. 11th edition. Edited by Ross A, Caballero B, Cousins R, Tucker K, Ziegler T. Lippincott Williams \& Wilkins; 2012:660-677.

35. Shaoul R, Gaitini L, Kharouba J, et al: The association of childhood iron deficiency anaemia with severe dental caries. Acta Paediatr 2012, 101:e76-e79.

doi:10.1186/1471-2431-13-174

Cite this article as: Schroth et al: Vitamin D status of children with severe early childhood caries: a case-control study. BMC Pediatrics 2013 13:174.

\section{Submit your next manuscript to BioMed Central and take full advantage of:}

- Convenient online submission

- Thorough peer review

- No space constraints or color figure charges

- Immediate publication on acceptance

- Inclusion in PubMed, CAS, Scopus and Google Scholar

- Research which is freely available for redistribution 